\title{
Developing Equipment Manufacturing Industry of Ha-Da-Qi Industry Corridor Under the Strategy of "The Belt and Road"*
}

\author{
Jiaqi Gao \\ School of International Studies \\ Shenyang University \\ Shenyang, China
}

\author{
Shumei Wang \\ School of Business and Management \\ Shenyang University \\ Shenyang, China
}

\author{
Huimin Li \\ School of Business and Management \\ Shenyang University \\ Shenyang, China
}

\begin{abstract}
The equipment manufacturing industry is the leading industry of Ha-Da-Qi Industrial Corridor, its development not only affects the development level of Ha-DaQi Industrial Corridor, also play significant role to the revitalization of Heilongjiang Province and Northeast China. But the development of equipment manufacturing industry of Ha-Da-Qi Industrial Corridor has met the bottleneck. Based on the theory of cluster analysis, this paper made an analysis of the agglomeration degree of equipment manufacturing industry in Ha-Da-Qi Industrial Corridor by employing location quotient in terms of overall level and subdivision sectors. Under the background of The Belt and Road, this paper put forward suggestions to boost the equipment manufacturing industry rapid implementation of "going out" to sustain economic growth. Ha-Da-Qi industrial corridor should grasp opportunities, expand the opening to the outside world, encourage the equipment manufacturing industry wellknown enterprises to go global and high technical talents to come in strengthen the equipment manufacturing industry and producer services joint, promote enterprise merger and reorganizations etc.
\end{abstract}

Keywords-The Belt and Road; Ha-Da-Qi Industry Corridor; equipment manufacturing industry; agglomeration degree

\section{INTRODUCTION}

As the first industrial base established in the northeast, the Northeast China made outstanding contribution to the economic development of the new China. However, after more than half a century of development, the economic development of the northeast region has been stagnant and declining, and the economic downward pressure of Heilongjiang province is particularly significant. In 2014, its economic growth rate was last but one nationwide, the last

*This paper is sponsored by National Soft Science Project (Project No 2014GXS4D095), and Shenyang Science and Technology Planning Project (Project No. F16-233-5-03, 17-232-5-04) one in the three provinces of Northeast China. In 2015 Heilongjiang's economic growth has rebounded, but it is still in recession. Area of Ha-Da-Qi industrial corridor is the strongest economic strength in Heilongjiang Province, with the highest industrialization, which can directly impact the economic development of Heilongjiang province and even the northeast area.

The strategy of Ha-Da-Qi Industry Corridor is formally proposed in 2005. Three cities form a line, and the planning and construction land of Ha-Da-Qi Industrial Corridor is 837.1 square kilometers. The industrial economic zone built along $200 \mathrm{~km}$ 's highway, covering three cities and two county-level cities, which are Harbin, Daqing, Qiqihar, Zhaodong and Anda. The whole corridor takes high technology, equipment, automobile, chemical industry, energy and food industry as major fields to form modern industrial belt. Encouraged by national preferential policies, Ha-DaQi Industry Corridor has achieved remarkable results.

The equipment manufacturing industry is an importan part of the national economy. All the developed countries in the world take equipment manufacturing industry as the basis for development and support. With the acceleration of the process of industrialization in the world, the development of equipment manufacturing industry is more and more dependent on Industrial aggregation. There is a positive correlation between the degree of Industrial aggregation and the local economic growth, that is, the higher the agglomeration degree of the equipment manufacturing industry, the stronger the industrial competitiveness, and the more growth of the local industrial economy [1]. The industrial chain of equipment industry is long and the degree of association is very high. These two characteristics also determine that Industrial aggregation is an important way to improve the competitiveness of the equipment manufacturing industry [2]. Therefore, to improve the degree of Industrial aggregation is crucial to the improvement of the 
competitiveness and regional economic growth of the equipment manufacturing industry in $\mathrm{Ha}-\mathrm{Da}-\mathrm{Qi}$ industrial corridor.

In 2013, President Xi Jinping put forward "The Belt and Road" economic development strategy, giving a new meaning for China's ancient Silk Road. "The Belt and Road" strategy is China's transformation of economic growth mode, deepen an important platform for interconnection with other Asian countries. It can not only take China's equipment manufacturing industry out of overcapacity predicament in the short term, but also promote domestic investment diversification, balance domestic regional economic development and improve China's economic influence in Asia in the long term [3]. Under the new environment, HaDa-Qi industrial corridor equipment manufacturing industry is facing both opportunities and challenges. The challenge is the Har-Da-Qi industrial corridor equipment manufacturing industry concentration is not high, and the annual industrial output value growth is weak since " 12 th Five-Year". Therefore, its development needs to find a breakthrough point, and then to improve industrial competitiveness, realize the rise of Ha-Da-Qi industrial corridor equipment manufacturing industry. The opportunity is to seize the new opportunities of "One Belt One Road", to take advantage of China, Mongolia and Russia economic corridor and boost the Ha-Da-Qi industrial corridor equipment manufacturing industry "going global", to further develop the broad Mongolia and Russia in the international market. Therefore, on the basis of concentration analysis theory, this paper use entropy method to calculate the location entropy of the equipment manufacturing industry in Ha-Da-Qi industrial corridor, identify the deficiencies in its development process, and combine with the "One Belt One Road" strategy to propose the advises to enhance industrial competitiveness of equipment manufacturing industry The results of this paper is very important to realize the equipment manufacturing industry to "go global" and promote the sustainable development of Ha-Da-Qi industrial corridor.

\section{LITERATURE REVIEW}

Industrial aggregation is an economic phenomenon with a certain scale and strong competitiveness in a specific area, so as to save production costs and transaction costs. This kind of geographical aggregation will help to improve the efficiency of the allocation of resources, enhance the industrial competitiveness of the region and enhance the economic strength of the region.

According to the theory of regional comparative advantage, there are difference in production factor competitive advantages and external economy among different regions, which cause the difference in resources allocation efficiency among different regions. Benefits attract resources, so industry will gather in the location of high efficient allocation of resources and high economic benefits. Industrial location theory holds that transportation, raw materials, wages and other cost factors play a dominant role in geographic distribution. The best location of industrial enterprises is the lowest cost of industrial products. Vernon pointed out that the advent of new products and new performance need supplier familiar with consumer demand, in-depth communication with consumers; when a new product is gradually accepted by customers, in order to improve the competitiveness of products and reduce the cost, the production base will be gradually gathered in the market area [4], which cause agglomeration phenomenon. Generally speaking, the aggregation of industries plays an important role in promoting the economic development of the region. Regional competitiveness diamond model proposed by Potter, focused on the Industrial aggregation can greatly enhance the competitiveness of regional industrial cluster international, industry competition is much larger than the sum of the parts industry competitiveness, namely $1+1>2$.

Industrial aggregation is the behavior of upstream and downstream related enterprises in a certain industry chain to gather in a certain spatial area, which is bound to generate a level of aggregation, that is, the degree of industry agglomeration, which reflects the uneven degree of industrial distribution. At present, there are mainly four ways to calculate the industry agglomeration degree: location entropy method, industrial concentration rate method, standard deviation coefficient method and Herfindahl-Hirschman Index method. In view of the accuracy, authenticity and accessibility of statistics, and whether it can truly reflect whether the industrial clusters in the region have industrial concentration tendency, location entropy method is widely used by scholars in [5].

Location entropy method is generally applied in location analysis, and it is an important method to identify industrial clusters by judging the specialization degree of objects in spatial distribution. Regional location entropy can reflect the degree of specialization in one sector. The formula is: $L Q_{i j}=\left(E_{\mathrm{ij}} \div E_{i}\right) /\left(E_{j} \div E\right)$, which Eij is the industrial output value of $\mathrm{J}$ industry in I area; $\mathrm{Ei}$ is the total output value of $\mathrm{I}$ area; $\mathrm{Ej}$ is the industrial output value of the national $\mathrm{J}$ industry; $\mathrm{E}$ is the total industrial output value of the whole country. If a certain area of industrial LQ>1, the industrial distribution in the region is relatively concentrated, export related products relatively large share, the country has a certain competitive advantage; $\mathrm{LQ}=1$, in the area of the level of competitiveness of the industry and the national average level is relatively flat, the balance position; $\mathrm{LQ}<1$, indicating the industry is relatively dispersed in distribution in this region, the level of competitiveness is lower than the national average, a relative disadvantage [6].

\section{AGGLOMERATION MEASUREMENT OF EQUIPMENT MANUFACTURING INDUSTRY IN HA-DA-QI INDUSTRIAL CORRIDOR}

\section{A. Overall Level Measurement}

According to the method of location entropy, this paper calculates the location entropy of the equipment manufacturing industry in three cities (Harbin, Daqing and Qiqihar). See "Table I". From 2008-2011, the location entropies of the equipment manufacturing industry in the two cities of Harbin and Qiqihar are much higher than that of Daqing. The agglomeration degree of two cities in Harbin and Qiqihar fluctuate around 1. The degree of specialization 
of equipment manufacturing industry is the same as that of the whole country. However, the agglomeration degree of Daqing has been fluctuating around 0.1 , accounting for only $10 \%$ of the national average. But since 2012, the location entropies of the equipment manufacturing industry in Harbin and Qiqihar have dropped below 1, which mean equipment manufacturing industry in Harbin and Qiqihar are declining.

TABLE I. THE LOCATION ENTROPY OF THE EQUIPMENT MANUFACTURING INDUSTRY IN 2008-2013

\begin{tabular}{|c|c|c|c|c|c|c|}
\hline Cities & $\mathbf{2 0 0 8}$ & $\mathbf{2 0 0 9}$ & $\mathbf{2 0 1 0}$ & $\mathbf{2 0 1 1}$ & $\mathbf{2 0 1 2}$ & $\mathbf{2 0 1 3}$ \\
\hline Harbin & 1.29 & 1.35 & 1.21 & 1.06 & 0.76 & 0.69 \\
\hline Daqing & 0.07 & 0.13 & 0.13 & 0.09 & 0.10 & 0.10 \\
\hline Qiqihar & 1.37 & 1.20 & 1.07 & 1.06 & 1.06 & 0.94 \\
\hline
\end{tabular}

\section{B. Subdivision Sectors Measurement}

According to national industries classification, equipment manufacturing industry include seven categories, they are Metal Products sector, General Equipment Manufacturing sector, Special Equipment Manufacturing Sector, Transportation Equipment Manufacturing sector, Electrical Machinery and Equipment Manufacturing sector, Communication Equipment,
Computer and Other Electronic Installation Manufacturing sector, Instrument Manufacturing sector, and Office Machinery Manufacturing sector. "Table II" is the location entropy of the seven major equipment manufacturing sectors in three cities of Harbin, Daqing and Qiqihar. The data used are from the 2009-2014 China Industry Statistical Yearbook, Harbin Statistical Yearbook, Daqing Statistical Yearbook and Qiqihar Economy Statistical Yearbook.

TABLE II. LOCATION ENTROPy OF THE SEVEn MAJOR EQUIPMENT MANUfACTURING SECTORS

\begin{tabular}{|c|c|c|c|c|c|c|c|c|}
\hline Cities & ectors & $\begin{array}{c}\text { Metal } \\
\text { Products }\end{array}$ & $\begin{array}{c}\text { General } \\
\text { Equipment }\end{array}$ & $\begin{array}{c}\text { Special } \\
\text { Equipment }\end{array}$ & $\begin{array}{c}\text { Transportation } \\
\text { Equipment }\end{array}$ & $\begin{array}{c}\text { Electrical } \\
\text { Machinery }\end{array}$ & $\begin{array}{l}\text { Communication, } \\
\text { Computer and } \\
\text { Other Electronic } \\
\text { Installation }\end{array}$ & $\begin{array}{l}\text { Instrument, } \\
\text { and Office } \\
\text { Machinery }\end{array}$ \\
\hline \multirow{7}{*}{ Harbin } & 2008 & 0.33 & 3.28 & 0.92 & 2.13 & 1.14 & 0.09 & 1.08 \\
\hline & 2009 & 0.44 & 3.11 & 0.98 & 2.22 & 1.12 & 0.12 & 1.18 \\
\hline & 2010 & 0.41 & 3.13 & 0.77 & 1.82 & 0.87 & 0.10 & 1.17 \\
\hline & 2011 & 0.47 & 2.81 & 0.86 & 1.42 & 0.82 & 0.09 & 1.04 \\
\hline & 2012 & 0.47 & 1.97 & 0.74 & 2.45 & 0.69 & 0.06 & 0.74 \\
\hline & 2013 & 0.57 & 1.53 & 0.80 & 2.51 & 0.60 & 0.07 & 0.58 \\
\hline & Average & 0.45 & 2.64 & 0.85 & 2.09 & 0.87 & 0.09 & 0.97 \\
\hline \multirow{7}{*}{ Daqing } & 2008 & 0.16 & 0.06 & 0.36 & 0.03 & 0.06 & 0.01 & 0.06 \\
\hline & 2009 & 0.26 & 0.11 & 0.58 & 0.06 & 0.10 & 0.01 & 0.09 \\
\hline & 2010 & 0.31 & 0.07 & 0.65 & 0.06 & 0.10 & 0.01 & 0.10 \\
\hline & 2011 & 0.28 & 0.05 & 0.40 & 0.01 & 0.09 & 0.00 & 0.05 \\
\hline & 2012 & 0.23 & 0.12 & 0.41 & - & 0.11 & 0.01 & 0.06 \\
\hline & 2013 & 0.27 & 0.09 & 0.45 & - & 0.08 & 0.01 & 0.09 \\
\hline & Average & 0.25 & 0.08 & 0.48 & 0.04 & 0.09 & 0.01 & 0.08 \\
\hline \multirow{7}{*}{ Qiqihar } & 2008 & 0.40 & 2.97 & 6.08 & 1.60 & 0.23 & 0.01 & - \\
\hline & 2009 & 0.14 & 2.68 & 5.41 & 1.11 & 0.26 & 0.01 & - \\
\hline & 2010 & 0.24 & 2.24 & 4.94 & 0.99 & 0.17 & 0.003 & - \\
\hline & 2011 & 0.09 & 2.05 & 4.73 & 1.28 & 0.06 & - & - \\
\hline & 2012 & 1.07 & 1.58 & 3.81 & 6.35 & 0.17 & - & - \\
\hline & 2013 & 0.85 & 1.41 & 3.55 & 5.42 & 0.17 & - & - \\
\hline & Average & 0.47 & 2.16 & 4.75 & 2.79 & 0.18 & 0.01 & - \\
\hline
\end{tabular}

Three cities have the lowest location entropy in Metal Products sector, Communication equipment, Computers and Other Electronic Equipment Manufacturing sector, which mean they don't have industrial competitive advantages.

Location entropies of General Equipment Manufacturing and Transportation Equipment Manufacturing sectors in
Harbin is always greater than 1, the average location entropy were 2.64 and 2.09, which mean Harbin has strong competitive advantages on this two sectors, But the General Equipment Manufacturing sector showed a downward trend, falling from 3.28 in 2008 to 1.53 in 2013 
Location entropies of the subdivision sectors in Daqing are all less than 1 , the industry distribution is relatively dispersed, the development level is low, and there is no competitive advantage. But the Special Equipment Manufacturing sector has shown a good development trend in the recent two years, and the upgrading space is large.

Location entropy of Special Equipment Manufacturing sector in Qiqihar has remained above 3.5, the average value of 4.75; location entropy of General Equipment Manufacturing sector has remained above 1.4, the average value is 2.16; location entropy of Transportation Equipment Manufacturing sector in 2013 reached 5.42, the average value is 2.79. These three sectors have the highest aggregation degree in Qiqihar, and have competitive advantages. But Special Equipment Manufacturing sector and General Equipment Manufacturing sector showed a trend of decline.

\section{COUNTERMEASURES AND SUGGESTIONS FOR EQUIPMENT MANUFACTURING INDUSTRY IN HA-DA-QI INDUSTRIAL CORRIDOR}

The equipment manufacturing industry in Harbin and Qiqihar has a high degree of agglomeration and strong competitive advantage, which is mainly derived from the comparative advantage industries of the two cities. Harbin has a strong industrial base and scientific research in the field of aerospace technology. There are some large scale aviation equipment enterprises, such as Hafei Group, Dongan Group and also some aviation parts production and supporting enterprises. More and more enterprises have gradually shown a trend of aggregation. Qiqihar has a unique advantage in the production of heavy machinery equipment, especially in the field of Computer Numerical Control (CNC) machine tool and agricultural machinery equipment. There are two leading enterprises in the field of CNC machine tools, Qiqihar Heavy CNC equipment Limited by Share Ltd and Qiqihar No.2 Machine Tool (Group) Co., LTD. These two leading enterprises and some other supporting SMEs have formed an industry cluster in Qiqihar high tech Zone. The products have sold to European markets. In contrast, equipment manufacturing industry in Daqing has a low level of concentration and at a disadvantage. However, Daqing as the main base of China's petroleum is rich in petroleum resources, and the petrochemical industry is the dominant industry in Daqing.

Equipment manufacturing industry in Ha-Da-Qiqihar industrial corridor is in urgent need to seek new breakthrough, to further improve industrial competitiveness. From the results of equipment manufacturing industry agglomeration degree, the location entropy value is facing a downward pressure. Meanwhile, the total output value of equipment manufacturing industry in three cities is also stagnant. This shows that the existing agglomeration effect cannot meet the increase of the total industrial output value of the equipment manufacturing industry. Ha-Da-Qi industrial corridor equipment manufacturing industry should seek new economic growth point, to achieve the sustainable development of the whole area. "The Belt and Road" strategy has brought a good opportunity for equipment manufacturing industry to go global. Many countries along "The Belt and Road" are developing countries, and they have high market demand for infrastructure construction, and showing a growth trend year by year [7]. Heilongjiang province is located on the Sino Russian border, so it should take advantage of geographical advantages and actively promote the construction of "Sino Russian economic corridor". Therefore, in the background of "One Belt and Road", equipment manufacturing industry in Ha-Da-Qi industrial corridor should make full use of the existing industry aggregation effect, increase industry competitiveness, deepen international cooperation, and encourage well-known enterprises to expand overseas market.

\section{A. The Combination of "Go Global" and "Bring in"}

Encourage famous enterprises to go global and bring in high technology. Three sectors, General Equipment Manufacturing, Transportation Equipment Manufacturing and Special Equipment Manufacturing, have formed aggregation effect in Ha-Da-Qi Industrial Corridor. Local government should give preferential tax policy to related enterprises to encourage well-known enterprises with high capability to go global, which can promote the formation of supply chain with capital, technology and brand rapidly [8]. In addition, the local government should establish a coordination mechanism, to avoid unnecessary conflicts caused by different culture and level of development. On the other hand, large equipment manufacturing enterprises can invest in overseas markets, attract overseas talents, bring in advanced technology to speed up the introduction of technology absorption and innovation and gradually form their own unique brand effects.

\section{B. Interactive Development between Production Service Industry and Manufacturing Industry}

For a long time, the traditional manufacturing industry depends too much on labor-intensive products or capital intensive products in the low-end of the value chain. Product prices are controlled by international brand enterprises, which undoubtedly blow the traditional manufacturing industry. At present, manufacturing industry has complex structure and high technology content, which makes buyers demand new products, such as information consultation, after-sales service and other service needs. Therefore, the equipment manufacturing industry should conform to the market demand and interact with productive service industry to increase the depth and breadth of the equipment manufacturing industry. On the one hand, equipment manufacturing enterprises carry out high value-added services, such as after-sale service, information service, inspection and so on, to enable enterprises to shift from manufacturing to manufacturing services; on the other hand, establish better public service platform, including inspection, logistics, and information consulting, to reduce the transaction cost. At the same time, use policy support funds to help the development of small and medium-sized enterprises in order to form a complete supporting system of industrial chain, to provide solid foundation for overseas expansion. 


\section{Energy Cooperation Mode Innovation}

Compared with Harbin and Qiqihar, Daqing possess strong petrochemical equipment industry foundation and abundant oil and natural gas resources. But Daqing oilfield has been mining for 50 years, underground resources have been decreasing, and the price of oil has been decreasing. The goal of steady growth is more and more challenging. It is difficult to maintain sustainable long-term development only relying on limited resources. Ha-Da-Qi industrial corridor should seize the opportunities of "The Belt and Road" to take advantages of abundant resources of natural gas, coal, petroleum, non-ferrous metals and iron ore in Russia and Mongolia[9]. Chinese enterprises can strive to enter Russia and Mongolia, carry out the exploration, mining and refining of primary products abroad, and further process in China. Through the innovation of energy cooperation mode, ensure energy supply in China on one hand can also extend the industrial chain, drive economy growth in Ha-DaQiqihar industrial corridor on the other hand.

\section{CONCLUSION}

The equipment manufacturing industry is the leading industry of Ha-Da-Qi Industrial Corridor. Its development not only affects the development level of Ha-Da-Qi Industrial Corridor, also play significant role to the revitalization of Heilongjiang Province and Northeast China. After analyzing the agglomeration degree of equipment manufacturing industry in Ha-Da-Qi Industrial Corridor, this paper found that the development of equipment manufacturing industry of Ha-Da-Qi Industrial Corridor has met the bottleneck. Under the background of The Belt and Road, Ha-Da-Qi Industrial Corridor should, encourage wellknown enterprises to expand overseas market; attract overseas technical talents , Boosting the interactive development of the equipment manufacturing industry and producer services, innovate energy cooperation mode.

\section{REFERENCES}

[1] Liu Lina, Jiao Fangyi, An Empirical Analysis of the Level of Equipment Manufacturing Agglomeration in Heilongjiang Province, no. 11. China: Northern Economy and Trade, 2008,pp,37-39.

[2] Zhao Zhonghua, Hu Yunquan, Concentration Analysis of Equipment Manufacturing Industry, no.4. China: China Soft Science, 2009, pp.50-55.

[3] An Shuwei, Impact of the "Silk Road Economic Belt and Maritime Silk Road" for China's Regional Economic Development, no. 4. China: On Economic Problems, 2015, pp.1-4.

[4] Liu Wenyong, Empirical Analysis on Agglomeration in China's Equipment Manufacturing Industry, no.6.China: Economic Theory and Business Management,2011,pp.103-112.

[5] Xiu Guoyi, Fu Meng, Measure of Concentration Ratio of Equipment Manufacturing Industrial Cluster in Heilongjiang Province by Location Quotien, no. 2. China: Science-Technology and Management,2014,pp.16-20.

[6] Zhou Tao, Liu Jishen, Study on Agglomeration Degree of Agriculture Product Processing Industry Based on Location Quotient - A Case of Northeast China, no. 5. China: Journal of Industrial Technological Economics, 2013, pp.78-83.
[7] Zhang Houming, A Research on the China's Equipment Manufacturing Industry "Going Global" Under the Strategy of "One Belt and One Road" Strategy, no. 6. China: Industrial Economy Review, 2015, pp.9-15.

[8] Xu Ce, Zou Lei, Energetically Promoting China Equipment Industry to Go global, no.5. China: Macroeconomic Management, 2015, pp.16-19.

[9] Chen Yan, Analysis on the Cooperative Development Path of ChinaMongolia-Russia Economic Corridor under the Belt and Road Strategy, no.6. China: Social Science Journal, 2015, pp. 133-135. 